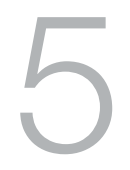

\title{
'Working the Mobile': Giving and Spending Phone Credit in Port Vila, Vanuatu
}

\section{Daniela Kraemer}

\section{Introduction}

Even if they have only just met, young people in Port Vila, Vanuatu, are quick to ask each other the question: 'Yu gat wan mobael?' (Do you have a mobile phone?). Inquiring whether a person has a mobile is a euphemism for asking to input a person's phone number into one's network so that it can be called or texted in the future. Asking for a person's phone number, even after just meeting, is common. So much so that, when I asked Alfred, age 22, whether he had a mobile - we were arranging to meet the next day, he exclaimed: 'E kan! Text i fulap!' (Oh shit! I receive lots of texts!). Alfred fussed that too many people had his number resulting in him receiving, and thus having to decide about responding or not responding to, 'too many texts'.

Most young people in Port Vila own their own mobile, which, like other youth worldwide, they use frequently. Handsets can be seen, and rings and vibrations can be heard, at all hours of the day and night - in town, on the roads, in yards, in the bush and in kava bars. Young people use the phone's flashlight, MP3 player and, of course, its calling and texting functions. 
What is most interesting about Port Vila young people's use of the mobile phone technology, however, is that while subscribers in the United Kingdom, United States and Canada use the phone to communicate with known contacts, in Port Vila, the mobile is valued as a tool to build new relationships with unknown contacts. In Vanuatu, people use the mobile phone to phone and text random numbers and start conversations and relationships with strangers. Indeed, by owning a mobile, a person gains access to a social network and all its potential relationships. For young people in Port Vila, mobile telephony is less about communication with family and friends than it is about broadening one's network of social relationships.

Informed by cultural understanding that social success comes through the accumulation of social relationships, young men give and receive mobile phone credit to build and manage their social relationships in an urban context in which they feel marginalised both by kin in town and by their home island-place connections (Kraemer 2013). Indeed, for Alfred and young men like him, the phone has become one of his most important assets and, if it is stolen or if his girlfriend breaks it during a row, as often happens (Kraemer 2015), he will go to great pains to acquire another one. Indeed, as this chapter will show, it is through the mobile phone that many urban young men are able to expand their social life and, with that, their status and renown.

Alfred is one of about 60 young men with whom I spent time during my doctoral fieldwork. Alfred and the other young men were all born in Port Vila and grew up and live in Freswota, one of Port Vila's residential communities. Their ages ranged between 16 and 28 - making them part of the first generation to come of age after Independence in 1980. As they were born and raised in town, their lived experience is remarkably different from that of their parents or grandparents, most of whom migrated to town from smaller rural islands at the time of Independence. As I will discuss later, their engagement with the kastom and tradition of their ancestral places as well as with their extended kin is diminished (Kraemer 2013). As such, unlike with previous generations, their social life is defined by the urban community in which they have grown up and the cosmopolitan group of neighbours and peers they live amongst. 
This chapter explores some of the ways relationships are currently being enacted in urban Vanuatu and the role that is played by mobile phone technology. It looks at how mobile phone consumers use the mobile phone in their quest to experience and create new forms of sociality, as well as the way the technology is being used to enhance the forms of sociality that already exist. For many Port Vila youth, the mobile phone has become the most essential tool used to mediate their relationships. With the new technology comes new opportunities, as well as risks. This chapter thus also explores the ways young people navigate new ideas, values and practices of relating to one another by means of their mobile phones.

\section{New Technology in Vanuatu}

Mobile phone technology is relatively new for most ni-Vanuatu. An employee of Vanuatu's first telecommunications company, Telecom Vanuatu Ltd (TVL), placed the first mobile call in 2001. In these early days, TVL employees were encouraged to make random phone calls in order to spark the population's consumption of the new technology. With few mobile subscribers to choose from, the man apparently dialled a random number, which led to a 'nice conversation' with an unknown female. This practice of 'random calling', especially by men looking for women, is a common occurrence in Vanuatu today.

In the early days of mobile telephony, most people could not afford a mobile phone. Statistics from a report published by the Pacific Institute of Public Policy (PIPP), show that, even in 2007 - six years after TVL's network launch - just 11 per cent of the country's population were mobile phone subscribers (Sijapati-Basnett, Brien and Soni 2008: 11). At this time, TVL was the only telecommunication provider in the country and people complained about its high cost and limited network coverage, and pressured the Vanuatu Government to amend the Telecommunications Act 2006 and open the market to competition (Sijapati-Basnett, Brien and Soni 2008: 11).

Eventually, in December 2008, a licence to operate was issued to Digicel, an Irish-owned company that was already established in the Caribbean and in other Pacific Islands states. Mobile subscriptions skyrocketed as the launch of Digicel broke TVL's monopoly and led to a drop in prices. Sijapati-Basnett emphasises the speed at which the new technology was 
taken up (pers. comm., 28 Feb 2012). In 2009, the time of the last national census, approximately 76 per cent of all ni-Vanuatu households (rural and town) reported using mobiles (Vanuatu National Statistics Office 2009: 27), and this number has certainly increased since then. As Toto, one of the young men I worked with, once exclaimed: 'Now every place has a mobile phone! Even a person on the islands who has never seen the lights of town, they already have a mobile phone.'

As has been documented in other developing countries, the mobile phone has quickly become the fastest form of communication between people. In Vanuatu, this is the case regardless of a person's social class or educational background because people with little to no regular income can still use the mobile phone's communication services.

The young people I spent time with in Freswota usually only had a few coins in their pockets. Most young women receive small amounts of money from family members for their housework and for looking after the children of family members working in the central business district of town. Young men earn small amounts of money through informal work such as yard work for neighbours, preparing kava for a family member's kava bar, participating in community projects such as building shelters for visiting market vendors or collecting firewood for community ceremonies. Young men also frequently coerce their formally employed girlfriends, sisters and female cousins for money, or resort to theft.

Young men spend less of their money on purchasing mobile phone credit, sometimes called 'talk-time', than young women. Instead, they use a variety of techniques, both improvised and made available by the phone companies, to communicate as much as possible for free. Young women also use these techniques when their purchased talk-time runs out. Similar innovative use of the mobile phone technology for communication has been reported for mobile phone users elsewhere (see Horst and Miller 2006 for Jamaica; Andersen 2011 for Papua New Guinea; Archambault 2012 for southern Mozambique).

In Vanuatu, Digicel allows mobile subscribers who do not have credit to make 'credit requests' of other people. A credit request entails the transfer of phone credit between two phones on the same network. A person requests credit by typing into the mobile ${ }^{*} 198 \#$ then the contact number of the person from whom one wants to 'request credit' and then \# and the amount of credit one wants. Usually the requests are for small amounts 
of phone credit such as $20 \mathrm{vt}$ or $50 \mathrm{vt}$ (AU\$0.24, AU\$0.60, respectively). It is both free to send these credit request messages and free to transfer the credit. Youth send credit requests to people whom they suspect have credit in the hope that credit will be shared.

The second technique is the sending of no-cost, pre-written 'plis kol mi (please call me)' text messages to people with whom they want to speak in the hope that the recipient will use their credit and ring back. Lastly, while it is not a specific feature of the phone's technology, young people who have some credit use the mobile in a creative way - they make a 'missed call' (mekem mest kol). In Port Vila, this practice is also known as 'choking the phone' (jokem fon). The person rings the number of the person they wish to speak to and then hangs up after one ring. The hope is that when a person sees that their phone has been 'choked', they ring the phone number using their own credit.

Since many of the young people I spent time with in Freswota did not usually have credit, or only had a little credit, these three techniques were used frequently in the hope that someone with credit would send them credit, or the person with whom they wished to speak would have credit or find credit through their own credit requests and then return their call.

When young men like Alfred had credit, they would be particularly savvy about whose please-call-me texts they would reply to and to whom they would give credit. This is because, as the rest of this chapter will explore, their mobile phone etiquette has become one of the most important ways to create and develop relationships and social networks.

\section{Access to Value}

One problem faced by many of the young men I worked with is a lack of access to economically valued items. Following Independence, the cost of education became unaffordable for most families and many in this generation had no choice but to leave school - most only obtaining a Year 6 education. Without a high school certificate, many find themselves sidelined from the formal wage economy and unable to earn a sufficient and stable income. 
Additionally, these urban young men are disconnected from their home islands. As transportation between islands has become unaffordable for many families in town, paren ts have not been sending their children to spend time on their home islands as previous generations did (see, for example, Tonkinson 1977; Lindstrom 2011). The consequence is a weakening of urban young people's relationship with the ground of their home island place and with the extended kin of their place (Kraemer 2013). For many of the young men I worked with, being outside this important kinship system means that they do not have access to its support and resources. Moreover, it means that they find themselves outside the customary system of gift giving and the circulation of valued goods. As such, many young urban men find themselves in the problematic and precarious condition of being without the means to establish and maintain enduring supportive social relationships, both in town and in the home islands.

It is not surprising, then, that the young men are not hopeful when they talk about their future. They see themselves as not having the means to move forward in life. Indeed, most of the young men I spent time with, even those in their mid and late 20s, were living with their parents. This was the case even when they had partners and children of their own, as many of them did. Alfred's best friend, 21-year-old Gerome, often lamented this situation. In his words:

On the island a boy age 21 would have everything. He would have his own garden and yams. He would have pigs. His family would have helped him build a house and soon he would take a wife. But a boy who is 21 years old in town has nothing - no house, no job, no money, no wife, and no chance to have these things in the future. I have nothing and this is why I'm not yet a real man.

Allusions to diminished manhood were common amongst Gerome and his friends. They experience this as an existential problem - seeing themselves as ineffectual men, in a state of permanent youth (Kraemer 2013). For them, it is through participation in economic life that ni-Vanuatu social life is lived and male wholeness is fulfilled.

Anthropological literature has demonstrated the historical significance of gift giving in the formation and management of social relationships in Melanesia. Anthropologists have provided many examples of Melanesians developing relationships and relationship networks through the giving of 
pigs, mats, yams, kula necklaces and armbands (Malinowski 1966; Munn 1986), and cooked and uncooked foods (Kahn 1986; Munn 1986), amongst other valued items.

The development of relationships through giving has continued with the use of money. In Port Vila, young men and women give friends and family members small amounts of money when they have it. The gift of a small amount of money symbolises the importance of the relationship. One urban tradition demonstrates this explicitly: people in committed relationships give their partner a sizeable portion of their first pay cheque. This act was explained to me in terms of making a 'small contribution' to feed the relationship. Just as with the kastom economy, when a person does not give or stops giving, the nature of the relationship is affected. This is especially true in young people's intimate relationships in Port Vila, where not giving some of the money that one has is considered to be an act against the relationship.

Most of the young men I worked with were not formally employed and nearly all had given up on ever finding jobs. While more educated and thus employed urban youth are able to make monetary contributions, or can purchase kastom economy to give as gifts to create and maintain relationships, most of the young men I knew did not have this option and experienced this as a significant deficiency in their lives.

Such is the context in which urban young men are exchanging mobile credit and talk time. Informed by cultural ideas and practices in which the exchange of items - be they mats, pigs or money - is key to a person's social development, relationships, status, growth prestige, fame and power, they are exchanging what they do have access to - mobile credit and talk time - in order to develop and manage their social worlds.

As we see, there is more going on in the young men's use of mobile phone credit than using it to communicate or disseminate information. Rather, urban young men are giving and spending mobile phone credit, an item they do have access to, as a way to participate in an exchange system that serves to develop relationships and build and maintain a social network. 


\section{Accumulating Mobile Phone Credit and Building up Relationships}

To engage in the system, phone credit is needed. Young men like Alfred accumulate phone credit not buy buying it themselves, but by building up a network of people who will respond positively to credit requests they send them - romantically interested young women, employed cousins and siblings, employed neighbours and politicians seeking their support. In a similar vein, they also try to limit how many 'mosquitoes' have access to their number. In Port Vila, 'mosquito' is a term used to describe people who regularly ask others for something but never make a return. These mosquitoes are viewed as consuming other people's sugar or valued items. The young men I worked with were selective about which phone relationships to engage in and, before giving out their number, they consider whether the phone relationship would be taxing, non-reciprocal and unenduring, or worth encouraging and finessing.

Accumulating mobile phone credit is so important to Alfred and young men like him that they pursue it at every opportunity, even stealing it from peers. One way this was done was by discreetly transferring credit off another person's mobile. Alfred was a master of this. He would tell, mostly young women he was flirting with, that he wanted to look at their phones. He would then send a credit request for a small amount of credit from his phone to the woman's phone, discreetly answer the request, and then delete all evidence of this action. Alfred would be long gone before the young woman ever realised that her credit had been syphoned.

Young men go to these extremes to accumulate mobile phone credit because, for them, mobile phone credit has a greater value than the text or talk time it buys - its value is as an exchange item that has become instrumental to social networking.

Once credit is accumulated, young men 'work hard' (had wok) sharing or not sharing it with others. Giving mobile phone credit is a way to expand one's network and it is not uncommon for someone to send a stranger credit to instigate a conversation and a relationship. I learned this firsthand not long after I started my fieldwork when I naively gave 15-year-old Tommy, one of my neighbours, my phone number after he asked for it. I wrote in my field notes that night that 'my phone keeps ringing. It's Tommy. First he sent me a 'please call me', then he 'choked' my phone or did a missed call. Then he called 5 times in a row. Then he sent me 100vt credit (AU\$1.20) and texted asking whether I had received the credit. It was 
only when I asked another neighbour, Griffith, to answer Tommy's call that Tommy hung up and didn't call again. Griffith explained that this was an extreme example, that Tommy had just come from the islands and did not know mobile phone etiquette. Griffith said that Tommy's intention with sending me phone credit was to establish a relationship with me. An important point is the finesse of establishing relationships through the giving of phone credit. It is a finesse that, according to Griffith, Tommy, 'fresh from the islands', had not yet learned.

Once a relationship is established, a person can be pressed for money, alcohol, food, clothes and/or additional phone credit to be used to request these items from other contacts. Indeed, Alfred shared his credit with a large network of his peers. They returned his 'generosity' with loyalty and support. Moreover, whenever they happened upon an item of value, such as a bottle of whisky or a bag of marijuana, they would offer Alfred the first taste.

Yet, at least in the initial interaction, the relationships created through giving mobile phone credit, even to strangers, is not based on establishing an obligation on the part of the recipient of the credit to make a return. Rather, as I believe was the case with Tommy, phone credit is given as a tool that works to instigate a relationship that would otherwise not develop, in the hope that this will lead to further gain one day. Horst and Miller (2006) suggest a similar use of phone credit in the context of Jamaica, where Jamaicans give credit to one another not on the expectation of reciprocity but out of a general sense that giving is a further opportunity to 'link-up' - extend and maintain a social connection that has the potential for a positive return in the future. In Port Vila, however, where many urban young men live economically precarious lives, young men are careful not to give phone credit to individuals who they believe will never make a return. This is why Alfred hesitated to give me his number - he had not yet ascertained what kind of phone relationship I would provide. Unlike Tommy, Alfred 'works the mobile' with greater skill.

\section{Modulating Relationships}

For Alfred and others, the giving of mobile phone credit has become an important part of developing a social life. Yet, giving and spending credit is not only for building social relationships, it is also a means to modulate relationships as they develop. Indeed, the reason Alfred joked with me about having too many contacts and receiving too many texts is because 
the more people who have his number, and the more requests he receives, the more he is forced into making explicit those relationships he values and those he does not. As Archambault has written in the context of Mozambique, 'since the entry of mobile phones, one's commitment to a relationship has in fact become easily demonstrable and quantifiable by the money spent' (2012: 39; see also Horst and Miller 2006).

Giving and spending phone credit in a relationship has become a signifier of the value of that relationship to a person. People give to relationships that they want to endure, and do not give to relationships they do not think will be sufficiently supportive or economically or socially profitable. In Port Vila today, it is through phone-mediated giving that people's relationships and enduring commitment are both demonstrated and maintained.

The use of phone credit in this way can be likened to what anthropologists have reported about other gift giving in Melanesia. As Nancy Munn wrote of the Gawan people of Papua New Guinea, certain positively valued acts, such as the giving of food to strangers, or negatively valued acts, such as not giving food, generates the kinds of subjectivities that form the social relationships (Munn 1986: 13). Indeed, among young people in Vila, giving credit creates and activates relationships, while not giving stops relationships from developing.

As I suggest, among unemployed urban young men, phone credit is assigned a value that is more than just its function in allowing for communication. Young people use the giving of phone credit as 'a tangible means to express their relationship with one another' (Taylor and Harper 2003: 159). Phone credit is not given, or is given in calculated amounts, as a means to modulate and maintain a desired degree of intimacy.

A phrase used often by urban young women demonstrates this point. A euphemistic equivalent of the English 'are you still dating him?' is 'does he still ring?' If a boyfriend has stopped ringing, the ignored partner will confront them with the phrase: 'You don't ring anymore! You don't love me'. What this means for Vila young people is that they are evaluating and demonstrating their relationships by the spending or the not spending of phone credit on them.

Throughout Vanuatu, it is socially unacceptable to explicitly deny a request. People generally ignore requests or say that they will think about a request but then never respond. In a similar vein of obfuscation, urban 
young men use the phrase 'I have zero balance' to reject a request without recrimination. While originally the phrase referred to not having any credit on one's mobile phone, it is now also used as a general term of one's financial state. Saying that one has zero balance allows a person to deny a request and avoid the social recrimination of doing so. Interestingly, the phrase has also become a signifying term of relationships. When a person tells his or her friends that he or she has zero balance, he or she is also acknowledging that his or her ability to make new relationships and manage existing relationships has been momentarily halted.

\section{Masculinity and Renown}

Young men also amass credit in order to spend it in acts that assert their masculinity. We see this with the actions of another young man with whom I worked, 25-year-old Toby; although, in Toby's case, his display did not go according to plan. One afternoon Toby recounted to me what had happened earlier that day while he was collecting data for the Vanuatu national census. As he walked around the neighbourhood, a friend asked him to ask the female census worker, Rose, 'whether she had a mobile?'

Toby asked Rose and she wanted to know who was asking. When Toby pointed to his friend, Rose replied that she had a boyfriend. Toby told me that he took offence to her rejection of his friend and decided to retaliate. Toby stole their census supervisor's list to get Rose's phone number. He then traded his T-shirt with another friend for a new SIM card and used it to phone her. Toby said that Rose hung up when she recognised his voice. But, not much later, Toby received a text message from Rose requesting that he send her credit. Toby sent credit and soon his phone rang displaying Rose's number. He answered it, however, it was not Rose's voice it was Rose's brother who reprimanded Toby for disrespecting a woman by stealing her number and calling her.

Toby told me that it got worse. A few minutes later, he received a message asking that he text them a woman's phone number for the brother to call. Toby explained to me that he felt used and so he used swear words in his return text. Having now run out of credit, Toby sent Rose a 'credit request'. Rose texted that she would send credit so they could keep texting but she never did and that was the end of their conversation. Toby told me that this exchange made him cross. He said, 'One day I will find her. She will forget this thing, but I will never forget it and I know her name!' 
In this scenario, Toby used his resources to access a new SIM card and phone credit to engage with Rose. It is likely that his plan, as I observed of many young men who feel slighted by young women, was to 'teach her a lesson'. Perhaps he intended to swear at her and insult her as a demonstration of his 'masculine potency'. In any case, what is important here is that his medium of choice was the mobile phone. Had this exchange ended differently, with Toby not appearing foolish, this would have been an example of how young men use amassed credit to assert the masculine power that they experience as diminishing in the urban context.

Toby realised the humour in this story and was not shy about sharing it with me and with his other friends. Indeed, for young men like Toby and Alfred, phone credit is used to instigate fun with their peers. While shared experiences are created through this process, using the phone credit in this way has the added value of creating fame and renown as stories, especially funny ones, spread quickly. Toby and his friends laughed about the incident with Rose and recounted the story to those who hadn't heard it for many days.

The TVL official slogan states: 'storian hemi laef' (to tell stories is to live). This marketing slogan refers to the history of Vanuatu as an oral society with a strong tradition of storytelling. Young people in Freswota spend much of their time telling stories. Yet, today, the mobile phone is being used not only to communicate stories with others, but to make stories as well. Young people do this by playing practical jokes and tricking people by means of the mobile phone - as occurred between Rose and Toby.

This was also the practice of one of my female friends, Lisa, who was then aged 17. When Lisa realised her boyfriend did not know she had a second mobile phone, she used credit that another friend had sent to her first phone to text her boyfriend under a false name. She teased and flirted with him under this false name until her credit ran out. Throughout she laughed at the fun 'we' were having tricking him like this.

We see here that Toby and Lisa both used their mobile phone credit to entertain people. This is a favourite way for urban young people to spend credit, and young men especially do not keep credit for long but spend it interacting with others. For them, phone credit is to be used to create social relationships, build up a greater relationship network and, through practical jokes using the mobile phone, create shared experiences and stories that potentially bring them renown and fame. 


\section{Conclusion}

Young people in Port Vila frequently exclaim that their lives have become busy 'working the mobile'. This euphemism points to what I have been discussing - that Port Vila young people, especially unemployed young men, spend time and effort occupied with the accumulation of phone credit, giving or not giving credit, and using credit to build their social networks. They also give credit to modulate their levels of intimacy with community members with whom they have little or no prior social relationship. Giving and spending credit additionally enables them to display their masculine power and garner fame amongst their peers.

For young men like Alfred and Toby, who have learned to accumulate phone credit, finesse 'phone relationships' and give and spend credit, the process often leads to the return of equal or greater value, and enhances their status and renown amongst their peers.

In keeping with previous Melanesian traditions of gift giving, 'working the mobile' has become a form through which young people perform their Melanesian personhood - developing a social life and social success through the act of giving. Indeed, for many of these urban young men, like 'Big Men' before them, giving and sharing, and not giving and not sharing, is the necessary 'work' for a successful social life. Moreover, such innovative use of phone credit demonstrates the resilience and creativity of Port Vila young men who are increasingly marginalised and ignored in their communities.

\section{References}

Andersen, B. 2011. Send Credit Please: 'Phone Friends', Financial Mobilities and Gendered Self-Fashioning in Urban Papua New Guinea. Paper presented at the annual meeting of the American Anthropological Association. Montreal, November 16-20.

Archambault, J. 2012. Mobile Phones and the 'Commercialization' of Relationships: Expressions of Masculinity in Southern Mozambique.

In Super Girls, Gangstas, Freeters, and Xenomaniacs: Gender and Modernity in Global Youth Cultures. K. Brison \& S. Dewey, eds. Syracuse University Press. 
Horst, H. \& D. Miller 2006. The Cell Phone: An Anthropology of Communication. Oxford: Berg.

Kahn, M. 1986. Always Hungry, Never Greedy: Food and the Expression of Gender in a Melanesian Society. Cambridge University Press.

Kraemer, D. 2013. Planting Roots, Making Place: An Ethnography of Young Men in Port Vila, Vanuatu. PhD Thesis. Department of Social Anthropology, London School of Economics.

2015. 'Do You Have a Mobile?' Mobile Phone Practices and the Refashioning of Social Relationships in Port Vila Town. The Australian Journal of Anthropology (TAJA), 28(1): 39-55. doi.org/10.1111/ taja. 12165

Lindstrom, L. 2011. Urbane Tannese: Local Perspectives on Settlement Life in Port Vila. Journale de la Société des Océanistes, 133: 255-66. doi.org/10.4000/jso.6461

Malinowski. B. 1966 [1922]. Argonauts of the Western Pacific. An Account of Native Enterprise and Adventure in the Archipelagoes of Melanesian New Guinea. London: Routledge and Kegan Paul.

Munn, N. 1986. The Fame of Gawa: A Symbolic Study of Value Transformation in a Massim Papua New Guinea Society. Cambridge University Press.

Sijapati-Basnett, B., D. Brien \& N. Soni 2008. Social and Economic Impact of Introducing Telecommunications throughout Vanuatu: Research Findings. Port Vila: Pacific Institute of Public Policy. dfat.gov.au/aboutus/publications/Documents/social-economic-impact-of-introducingtelecommunications-throughout-vanuatu-2009.pdf (accessed 14 April 2018).

Taylor, A.S. \& R. Harper 2003. The Gift of the Gab?: A Design-Oriented Sociology of Young People's Use of Mobiles. Computer Supported Cooperative Work, 12: 267-96. doi.org./10.1023/A:1025091532662

Tonkinson, R. 1977. The Exploitaion of Ambiguity: A New Hebrides Case. In Exiles and Migrants in Oceania ASAO Monograph No. 5. M.D. Lieber, ed. Honolulu: University Press of Hawaii.

Vanuatu National Statistics Office 2009. National Census of Population and Housing. Port Vila: Ministry of Finance and Economic Management. 
This text is taken from The Moral Economy of Mobile Phones: Pacific Islands Perspectives, edited by Robert J. Foster and Heather A. Horst, published 2018 by ANU Press, The Australian National University,

Canberra, Australia.

doi.org/10.22459/MEMP.05.2018.05 